\title{
Biological conservation of aquatic inland habitats: these are better days
}

\author{
Ian J. WINFIELD*
}

Lake Ecosystems Group, Centre for Ecology \& Hydrology, Lancaster Environment Centre, Library Avenue, Bailrigg, Lancaster, LA1 4AP, UK

*Corresponding author: ijw@ceh.ac.uk

\begin{abstract}
The biodiversity of aquatic inland habitats currently faces unprecedented threats from human activities. At the same time, although much is known about the functioning of freshwater ecosystems the successful transfer of such knowledge to practical conservation has not been universal. This alarming situation is considered here using a theme of the conservation of freshwater fishes, supported where appropriate with examples drawn from other taxa. Global awareness of aquatic conservation issues is also hampered by conditions under the water surface being largely hidden from the direct experience of most members of society. Connectivity, or lack of it, is another challenge to the conservation of freshwater habitats, while urban areas can play a perhaps unexpectedly important positive role. Freshwater habitats frequently enjoy benefits accruing from a sense of ownership or stewardship by local inhabitants, which has led to the development of conservation movements which commonly started life centred on the habitat itself but of which many have now matured into wider catchment-based conservation programmes. A demonstrable need for evidence-based conservation management in turn requires scientific assessments to be increasingly robust and standardised, while at the same time remaining open to the adoption of technological advances and welcoming the rapidly developing citizen science movement. There is evidence of real progress in this context and conservation scientists are now communicating their findings to environmental managers in a way and on a scale that was rarely seen a couple of decades ago. It is only in this way that scientific knowledge can be efficiently transferred to conservation planning, prioritisation and ultimately management in an increasingly scaled-up, joined-up and resource-limited world. The principle of 'prevention is better than cure' is particularly appropriate to most biological conservation issues in aquatic inland habitats and is inextricably linked to educating and/or nudging appropriate human behaviours. When prevention fails, some form of emergency rescue such as captive breeding or translocations may be justified for particularly important animal or plant populations. However, long-haul missions of habitat rehabilitation or restoration are generally to be preferred even if they may take decades to reach fruition. Conservation researchers, managers and practitioners must be realistic in their objectives and timescales for such programmes and take positive steps to communicate such information to stakeholders. Now more than ever, people are interested in conservation and sustainability. There are substantial challenges ahead, but these are better days for the biological conservation of aquatic inland habitats.
\end{abstract}

Key words: biodiversity, citizen science, evidence-based, freshwater fish, knowledge transfer, standardised assessment.

Received: May 2013. Accepted: July 2013.

\section{INTRODUCTION}

In December 2003, the United Nations General Assembly proclaimed the years 2005 to 2015 to be an International Decade for Action on the specific theme of Water for Life (Dudgeon et al., 2006). While the major actions aspired to within this resolution are concerned primarily with development efforts such as the provision of safe drinking water and basic sanitation, Dudgeon et al. (2006) argued that these important matters should not obscure the fact that this resolution comes at a time when the biodiversity and biological resources of inland waters are facing unprecedented and growing threats from human activities. As we approach the end of this International Decade for Action, the biological conservation of aquatic inland habitats continues to face intense challenges. As evidenced by other articles in this special volume, the international research community now knows a great deal about the functioning of both natural and perturbed fresh- water ecosystems around the world. Such understanding should in principle aid our wise and sustainable management of these precious areas. However, Dudgeon et al. (2006) and many others have observed that the transfer of such knowledge to the practical conservation of freshwater biodiversity has been largely unsuccessful, due in part to the special features of freshwater habitats that make them especially vulnerable to human activities. Indeed, in rapidly developing areas of the world, such as parts of Asia, some have even asked if inland aquatic biodiversity has a future (Gopal, 2005). Furthermore, although environmental issues including the conservation of freshwater biodiversity have benefitted from a heightened interest from society over recent decades, a recent analysis of internet search patterns suggests that some of this interest may now be declining (McCallum and Bury, 2013). If actually so, this is a negative development of great concern.

As a result of the above trends, scientific research is 
now needed more than ever to guide the conservation of the world's aquatic inland habitats. Such conservation-led research must be conducted alongside work addressing society's other needs and so should be undertaken with a positive, pragmatic approach. In this context, it is notable that a recent review by Brown et al. (2010) of priority water research identified by U.K. practitioners and policy makers identified 94 questions on nine themes, including freshwater biodiversity, communicating water research, and integrated catchment management. Freshwater science and particularly the ability to translate research into practice also appeared in a recent list of most wanted skills in the U.K. environment sector (LWEC, 2012). The persistent messages from these and similar reviews are that the global conservation of freshwater biodiversity must evolve to operate realistically in a complex world, often alongside competing objectives, and that environmental researchers must increase their efforts to transfer their scientific understanding to the benefit of environmental managers.

Here, some personal observations are offered on the nature and practice of conservation science as it relates to aquatic inland habitats. No attempt is made to produce a comprehensive review of this large and complex subject, but rather consideration is focused on how such conservation may be best achieved in what is usually a highly diverse and multi-use environment. These observations are approached using a theme of freshwater fishes and cover considerations of the single and synergistic threats facing aquatic inland habitats, some notable features of the latter in the context of conservation, their assessment and finally their management. The challenges are undoubtedly great, but it is argued that a number of recent developments give cause for optimism.

\section{A THEME OF FRESHWATER FISHES}

Any personal observations are of course likely to be both consciously and subconsciously influenced by the observer's own history and this article is no exception. Inevitably given the author's research and management experience, the predisposition here will be towards freshwater fishes. However, such a taxonomic bias has several positive aspects. Fishes have an extensive history of scientific study, even if much of it has been driven by fisheries interests. This body of evidence includes relatively early (for vertebrates) attempts at large-scale assessments of biodiversity loss (Moyle and Leidy, 1992) and the general recognition that freshwater species are among the most highly human-impacted faunal groups (Duncan and Lockwood, 2001). Contemporary studies of the in situ conservation of rare freshwater fish species typically involve habitat- or even catchment-based management actions (Winfield et al., 2012), while the high public profile and other characteristics of such species has facilitated a recent explosion in their ex situ conservation through a variety of novel means around the world including the active engagement of zoological societies and the general public (McGregor Reid, 2013). The conservation of freshwater fishes of aquatic inland habitats thus has a wealth of experiences, both negative and positive, from which the wider conservation of aquatic inland habitats may derive benefit.

\section{SINGLE AND SYNERGISTIC THREATS}

Dudgeon et al. (2006) include an extensive review of the threats facing freshwater biodiversity and group them under the five interacting categories of overexploitation, water pollution, flow modification, destruction or degradation of habitat, and invasion by exotic species (Fig. 1). Environmental changes occurring at larger spatial scales, such as climate change or nitrogen deposition, are superimposed on all of these major threat categories and may significantly influence their outcomes. Thus, even longestablished environmental threats to aquatic inland habitats such as acidification and eutrophication, which as single issues are now well understood and generally manageable given appropriate resources, now commonly operate on habitats also subjected to additional pressures such as changed flow patterns or higher temperatures. This results in impacts of potentially higher magnitudes and complexities.

Such synergistic effects of multiple single threats are rapidly becoming appreciated for a range of biota, with for example the complicating effects of climate change apparent for a range of aquatic organisms from macrophytes (Alahuhta et al., 2011) to fish (Jeppesen et al., 2012). Issues of habitat connectivity are paramount in many fresh waters as considered below, so it is unsurprising that invasions by exotic species including the synergistic influences of factors such as eutrophication, climate change and flow modification are a major issue around the world (Dunham et al., 2002; Kats and Ferrer, 2003; Hussner et al., 2010; Winfield et al., 2011; Hermoso et al., 2011; Liu et al., 2011). The persistent message from studies of specific threats is that the global conservation of freshwater biodiversity must operate in a complex world subjected to often competing environmental demands. Some of these constraints to conservation actions are common to the conservation of any broad class of habitats, but for aquatic inland habitats the importance of some of them is magnified by some notable features of such areas.

\section{SOME NOTABLE FEATURES OF AQUATIC INLAND HABITATS}

\section{A partly hidden world}

Arguably the most notable feature of aquatic inland habitats in the context of biological conservation is that 
to the human observer they constitute a partly hidden world. While their water surface and immediate surrounding habitats such as riparian zones may be highly visible, conditions under the surface are largely hidden from the direct experience of all but a few specialised interest groups such as anglers and indeed aquatic researchers and managers. As a consequence, background information or indigenous knowledge is often absent or certainly relatively lacking for such habitats and their scientific study is challenging. Encouragingly, recent and continuing developments in information technology, increased right of public access to environmental data and the mobilisation of citizen science (see below) are radically improving this situation. Nevertheless, public awareness of conditions below the water surface still often only becomes significant when it is prompted by visible catastrophic events such as algal blooms and potentially associated fish kills. A particularly well documented example of such an event is provided by the eutrophicated Loch Leven in Scotland, UK, where media coverage of a serious cyanobacterial bloom in the early 1990s precipitated a debate in the UK parliament on water quality issues (May and Spears, 2012a). This in turn led to an increase in local research effort and the development of an effective catchment management plan (May and Spears, 2012b). To help deliver effective conservation action in a world of limited research and management resources, it is essential that those responsible for or with an interest in aquatic inland habitats acknowledge this limited visibility of such areas and do all in their power to overcome it.

\section{Connectivity at its most consequential}

An awareness of habitat connectivity has long been acknowledged as crucial for the development of appropriate landscape-scale conservation strategies for terrestrial habitats (Bunn et al., 2000). As a result, effective

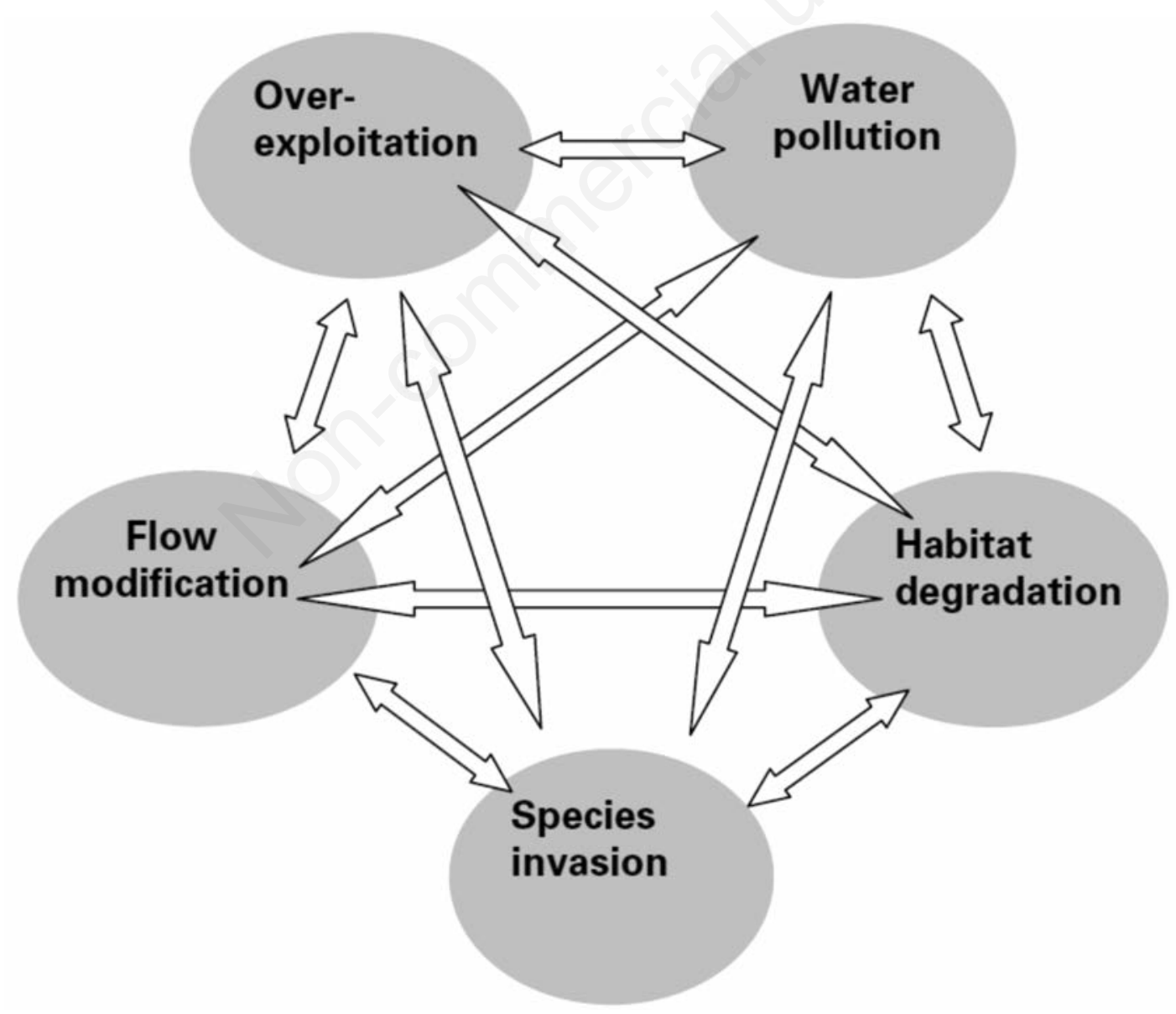

Fig. 1. Five major threat categories and their interactive impacts on freshwater biodiversity as identified by Dudgeon et al. (2006). Environmental changes occurring at larger spatial scales, such as climate change or nitrogen deposition, are superimposed on all of these major threat categories. Reproduced from Dudgeon et al. (2006). 
networks of terrestrial conservation areas now exist in many parts of the world. However, such terrestrial reserve networks do not necessarily also provide adequate protection for aquatic inland habitats (e.g. Herbert et al., 2010) and so rare aquatic species tend to be less well protected than their terrestrial counterparts (Fig. 2). Moreover, for obvious reasons, connectivity is often an even more important factor for freshwater habitats.

Such low aquatic connectivity can operate at very subtle levels. For example, local effects of forest fragmentation can have important implications for the conservation of stream insects even though the water course itself may remain continuous (Md Rawi et al., 2013). In truly physically isolated aquatic habitats such as many lakes, habitat connectivity can have even more significant conservation impacts on relatively sedentary biota such as macrophyte communities (O'Hare et al., 2012). Even otherwise highly mobile aquatic species, typified by many species of freshwater fish capable of long migrations, can be adversely affected by the loss of natural habitat connectivity following the construction of instream obstacles such as weirs and dams (Dugan et al., 2010). In many industrialised countries, the full ecological benefits of recent improvements in water quality have yet to be fully realised because persisting connectivity problems continue to impede natural movements and thus recolonisations by even highly mobile biota such as fish (Langford et al., 2010).

Conversely, the natural disconnected nature of many aquatic inland habitats renders them particularly susceptible to the accidental or intentional anthropogenic introduction of new species. Consequently, it is unsurprising that as discussed above Dudgeon et al. (2006) considered invasion by exotic species to be one of the major threats to freshwater biodiversity. Preventative actions revolving around biosecurity precautions against such unnatural connectivity are now understandably common around the world (Cliff and Campbell, 2012) and will be considered further below.

\section{Urban ubiquity and its utility}

As a result of humankind's predilection to settle in close proximity to fresh waters, most of the world's countries now contain substantial human population centres adjacent to their larger rivers and lakes. In developed countries, this means that substantial areas of fresh waters now lie within urban environments. While the levels of biodiversity within such aquatic habitats tends to be less than those encountered in less impacted rural areas, all is not lost and work in the USA has shown that the appropriate management of such areas, including the maintenance of riparian habitat, may help alleviate ecological disturbances to species such as macroinvertebrates even in highly urbanised catchments (Moore and Palmer, 2005). Indeed, in the Netherlands it has been found that urban drainage systems can sustain a macroinvertebrate biodiversity comparable with that of drainage systems in rural areas and thus have appreciable potential conservation benefits (Vermonden et al., 2009). In Poland, Koperski (2010) found that freshwater habitats within Warsaw supported populations of several rare and highly specialised leech species (Alboglossiphonia, Batracobdelloides, Dina, Glossiphonia, Hirudo spp.). With respect to the vertebrate inhabitants of aquatic inland habitats, Leidy et al. (2011) examined historical and recent records of the distributions of native stream fishes in catchments of the urbanised San Franciso Estuary, USA, and concluded that streams in spatially complex urban settings retain important conservation benefits for such biota, despite significant perturbations and the frequent establishment of non-native fishes. Perhaps most remarkably of all, until recently the Mexican axolotl [Ambystoma mexicanum (Shaw \& Nodder)] was thought to persist as just two highly threatened and isolated populations inhabiting the remnants of a historically extensive lacustrine system that once occupied the entire Valley of Mexico, but which has been effectively destroyed by the growth of Mexico City. However, in 2005 a third viable population was confirmed by Recuero et al. (2010) in Chapultepec park, a public recreational area in the heart of Mexico City. More generally, innumerable studies from around the world have

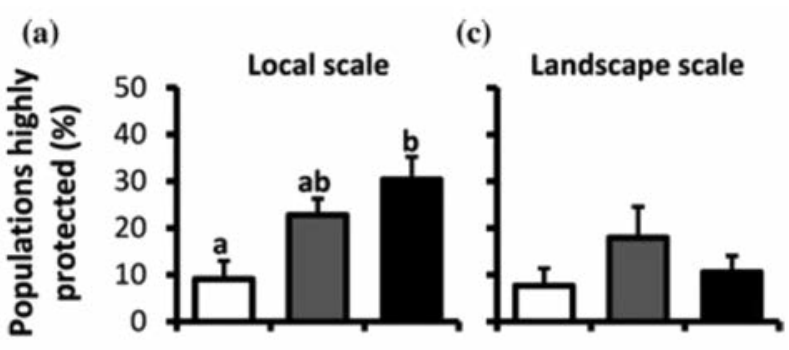

(b)

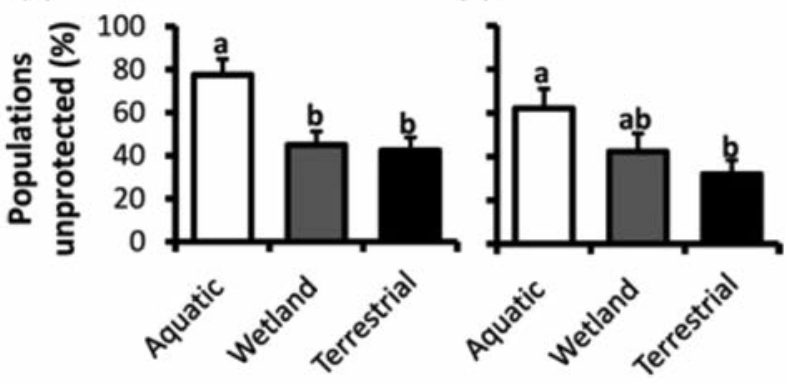

Fig. 2. The percentages of populations of rare aquatic, wetland and terrestrial species (a) highly protected at the local scale, (b) highly protected at the landscape scale, (c) unprotected at the local scale and (d) unprotected at the landscape scale in Michigan, U.S.A. Letters indicate significant differences between habitat types. Reproduced from Herbert et al. (2010). 
demonstrated that urban aquatic habitats impacted by diverse forms of environmental degradation have encouragingly proved to be capable of responding to appropriate restoration efforts (Moss (2012) and references therein). These and other findings emphasise the remarkably and perhaps unexpectedly important role that urban aquatic inland habitats can play in the conservation of highly threatened species.

\section{A common sense of ownership or stewardship}

The discreet nature of aquatic inland habitats, which contributes to the importance of appropriate connectivity for their well-being, also means that they are readily identifiable as delimited entities by local human communities. Furthermore, the frequent association of such habitats with urban areas discussed above, and with villages or even smaller population units in rural environments, means that most lakes and rivers have immediate and substantial human habitations. $\mathrm{s}$ a consequence of these and other factors, aquatic inland habitats are rarely ignored by society and more frequently enjoy appreciable benefits accruing from a sense of ownership or at least stewardship by local inhabitants. This may be a very specific sense of ownership such as that of fishing rights, which facilitates the control of fishing pressures, but more often such ownership or stewardship promotes a more general care of the local environment. Given the often unimpressive record of water body management by state government (D'Sousa and Nagendra, 2011), such involvement of the local community can be highly beneficial. For example, significant freshwater conservation groups such as The Mono lake Committee (www.monolake.org) in California, USA, and The Rivers Trust (www.theriverstrust.org) in the UK have their origins in small, local bottom up voluntary movements which have grown and developed over time. Moreover, while most such movements started life very much centred on the aquatic inland habitat itself, many have now matured into wider catchment-based conservation programmes and are becoming important mechanisms for the delivery of ambitious environmental actions such as the EC Habitats Directive (European Communities, 1992) and EU Water Framework Directive (European Communities, 2000).

\section{CONSERVATION ASSESSMENT AND ITS COMMUNICATION}

\section{On the need for objective, robust and communicable} assessment evidence

Conservation management is inherently a demanding activity given the complexities of habitats and species, which are further magnified by the addition of human management into the equation. Unsurprisingly, conservation has as a result frequently been practiced on a basis of conventional dogma which has itself sometimes been proven to be erroneous. Sutherland (2003) takes up this issue and draws striking parallels with the development of evidence-based medicine, presenting a convincing argument that the same approach should be taken to conservation. Such adaptive management has a long history in the environmental sciences (Holling, 1978), including applications to aquatic inland habitats such as the Columbia river in the Pacific North-West of North America (Lee, 1993). However, to be fully effective this approach requires the collection of objective, robust and communicable evidence which can be readily appraised and evaluated by conservation managers.

\section{Quantification and standardisation}

At the levels of the abundance and other features of species and the species richness of communities or parts of communities, at least for those where sampling can be effectively undertaken, a substantial volume of data (increasingly referred to as evidence by environmental managers) already exists for aquatic inland habitats in many countries. For example, Biggs et al. (2005) review the results and lessons of 15 years of pond assessments in Britain, while Cooke and Murchie (2013) do much the same over a considerably longer time scale for inland fisheries in North America. Comprehensive quantified assessment protocols are now available for many species of conservation interest, such as that described for Arctic charr [Salvelinus alpinus (L.)] by Winfield et al. (2009). Much current research is aimed at developing these species-specific assessments into community-wide or even habitat-wide quantitative assessments, with a recent example provided for European lake fish communities by Argillier et al. (2012).

Such quantification of ecological assessments is driven primarily by national and international conservation and environmental legislation, which has also increased the need for greater standardisation for sampling and assessment methodologies. Benefiting from a historical impetus from fisheries concerns, such standardisation for the assessment of freshwater fish populations, and thus fish communities, has been underway for many years (Bain et al., 1999) and has resulted in the development of standardised methods for use in North America (Bonar et al., 2009) and Europe (European Standard, 2005, 2006; Hateley et al., 2013). The truly global standardisation of such assessment methods is now becoming feasible.

\section{Technological advances and controlled methodological change}

At the same time that the standardisation of assessment methods is becoming increasingly common, conservation researchers and managers must also remain open to the adoption of technological advances and thus to con- 
trolled methodological change. At its simplest level, such changes may represent nothing more than minor technical developments in sampling equipment such as electrofishing or hydroacoustic equipment. Such technological evolution is relatively easily managed by comparative trials and, if necessary, the development of appropriate conversion factors between the older and newer systems. Similarly, the development and adoption of new assessment indices pose no problems if they are based on underlying population and community data that have themselves been collected using effectively constant, or inter-calibrated, techniques. The new indices can simply be calculated retrospectively using historical data.

Greater challenges arise in situations where community sampling methodology is not yet mature and so fundamental changes in sampling practices are still being made and may continue to be made into the future. In aquatic inland habitats, this problem is well illustrated by the fish communities of large lakes and reservoirs. As concluded by Kubečka et al. (2009), there is no single sampling technique which by itself adequately covers the entire fish community of such habitats. Consequently, in such situations researchers often use more than one technique simultaneously, such as combining survey gill nets and hydroacoustics (Winfield et al., 2009). Moreover, technique selection may also be influenced pragmatically by factors such as environmental conditions and the acceptability of destructive sampling to local inhabitants. As a result, there is significant value in determining the degree of consistency between observations produced by fundamentally different sampling techniques. Recent comparisons by Emmrich et al. (2012) of measures of lake fish abundance produced by simultaneous gill-netting and hydroacoustic surveys have been very encouraging in this context (Fig. 3). Even more revolutionarily, completely new avenues of potential assessment methodologies are opening up as a result of theoretical and technical advances. Amongst these, the field of conservation physiology (Cooke et al., 2013b) offers exciting opportunities for conservationists to expand from assessing environmental impacts at the levels of communities and populations to assessing them at the organism level. Cooke et al. (2013a) provide an excellent example of the value of this new approach with respect to the management of several species of Pacific salmon (Oncorhynchus spp.) in the Fraser River Watershed, Canada. Even more in its infancy as a technique, the detection of species in aquatic inland habitats using environmental DNA holds great promise. For invasive fish species in the Laurentian Great lakes of North America, this approach has already been shown to be more sensitive than traditional sampling techniques (Jerde et al., 2011).

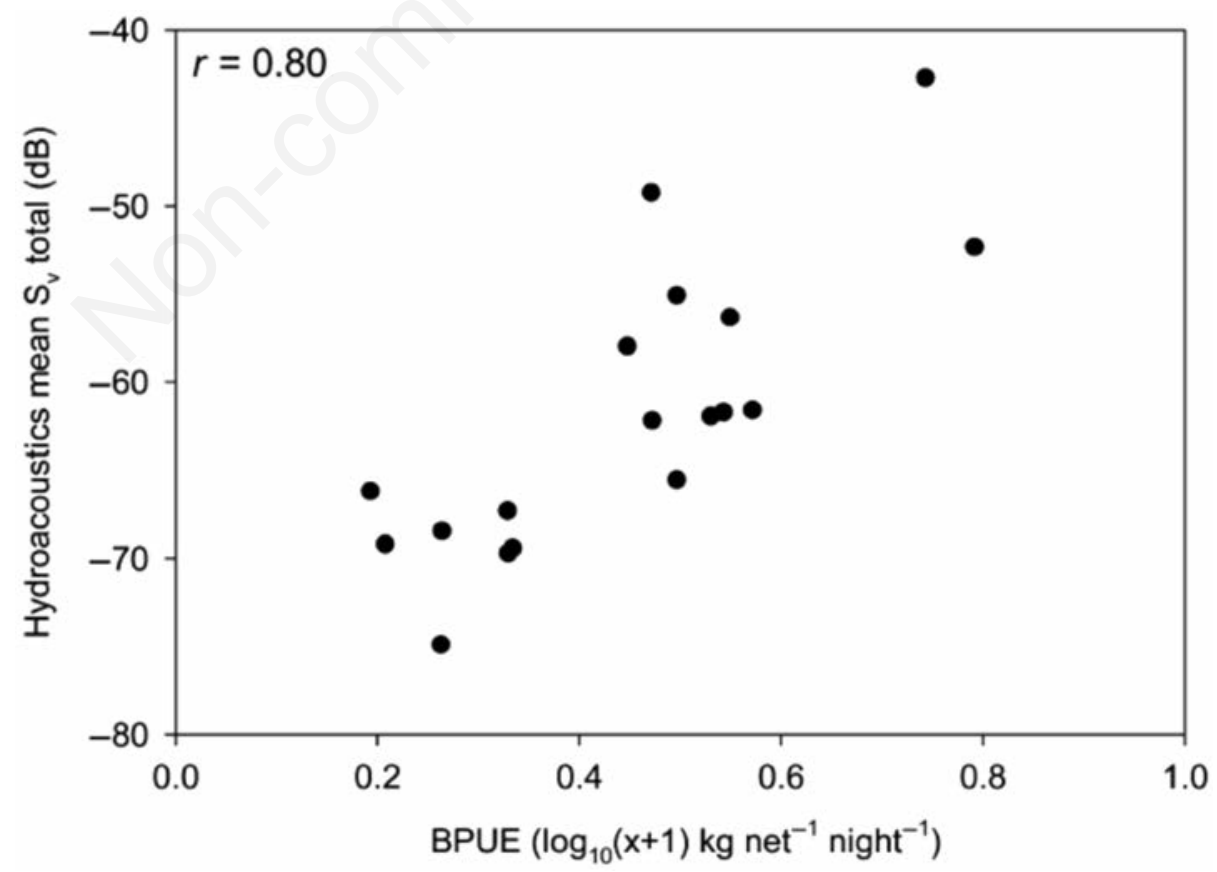

Fig. 3. Strong correspondence (Pearson's $r=0.80, \mathrm{P}<0.001$ ) between lake fish abundance assessed simultaneously by the old technique of survey gill netting (expressed as Biomass-Per-Unit-Effort, BPUE) and the new technique of hydroacoustics (expressed as total mean volumetric backscattering strength, $\mathrm{S}_{\mathrm{v}}$ ). Each of the 18 data points represents an individual lake from seven European countries. Reproduced from Emmrich et al. (2012). 
Finally, conservation researchers and managers must also be open to the developing benefits of citizen science in which data are collected not by scientists but by informed volunteers (Silvertown, 2009). The principal advantage of this movement is that it allows levels of sampling effort to be expanded far beyond those feasible using only scientists, although a further advantage is that it also promotes public engagement. This method of data collection has its origins in non-aquatic initiatives, but following its early development and adoption in North America exemplified by the 1974-onwards voluntary measurement of lake water clarity throughout Michigan, USA (Bruhn and Soranno, 2005), it is now being adopted across many aquatic inland habitats around the world. For example, it is being used in areas as diverse as the migration of young European freshwater eel [Anguilla anguilla (L.)] in rivers (Pecorelli, 2012), the monitoring of algal blooms in lakes (Fletcher, 2013), and the mapping of macrophytes in lakes (ciBioBase, 2012). The latter example relies on a web-based sophisticated analysis of data collected by volunteers using extremely user-friendly hydroacoustic systems, often during other activities such as recreational fishing. As such, it typifies the future of citizen science envisaged by Newman et al. (2012) to be dependent on emerging technologies.

\section{Communication}

Conservation science is by its very nature an applied activity. As such, it is essential that its research findings are actively taken from the laboratory to the meeting room and conveyed to those responsible for conservation policy and conservation actions. This crucial transfer of knowledge requires scientists to simplify their key findings, or at least learn to express them in terms understandable to the non-specialist. In this context, the development of relatively simple so-called scorecards has proved to be an effective means of succinct communication of complex ecological observations for water bodies (Watzin et al., 2005). As considered in some detail by Winfield (2010), this flow of information has historically not always been great but there are encouraging signs that things are changing. For example, a review by Sutherland et al. (2009) of 100 questions of importance to the conservation of global biological diversity arranged many of its components under the high-level headings of organisation systems and processes, societal context and change, and impacts of conservation interventions. Clearly, conservation scientists, including those not directly employed by conservation bodies, are increasingly taking their findings and communicating them to environmental managers in a way and on a scale that was rarely seen a couple of decades ago. However, there is still much to be done to encourage and facilitate such communication, not least of which is for research institutes and universities to for- malise reward structures for individuals involved in these challenging and time-consuming activities.

\section{CONSERVATION MANAGEMENT}

\section{Principles, planning and prioritisation}

This is not the place for a detailed review of the conservation management of aquatic inland habitats, but brief comments informed by recent research findings will be made on some of its general principles. First, however, it is appropriate to note the growing importance of conservation planning, including prioritisation, in an increasingly scaled-up, joined-up and resource-limited world.

In many countries, conservation planning has a substantial history. For example, a landmark review of the conservation of freshwater fishes in the British Isles published approximately 40 years ago included a call for better planning and better integration with the activities of others involved with the management of aquatic inland habitats (Maitland, 1974). Since that time, conservation planning has become more ambitious, more evidencebased and as a result more sophisticated. For example, Baldwin et al. (2006) have incorporated highly detailed radio-telemetry observations of wood frogs (Rana sylvatica LeConte) in the USA into conservation planning and as a result have reduced the amount of land potentially requiring protection by more than $66 \%$. At the other end of the planning scale, Bernazzani et al. (2012) have usefully distilled recommendations from the scientific literature to offer a series of recommendations for integrating climate change into habitat conservation plans under the U.S. Endangered Species Act. Their findings have clear applicability to conservation planning for aquatic inland habitats around the world.

A clear theme emerging from the literature is that conservation plans in a world of many pressures and limited resources have to be prioritised. Just how this difficult task is to be done most efficiently and most effectively has been considered by many researchers and many managers. At the broadest level, Holland et al. (2012) have examined setting conservation priorities for freshwater biodiversity using a 'Key Biodiversity Approach' applied to river and lake catchments in continental Africa. Also at a broad level, Beger et al. (2010) have developed a conceptual framework for systematic conservation prioritisation that explicitly accounts for the natural connectivity between marine, terrestrial and freshwater habitats. Many examples of more taxon-specific prioritisation abound in the literature, with typical examples being provided by Strecker et al. (2011) for threatened fishes in the Lower Colorado River Basin, USA, and by Clarkson et al. (2012) for threatened fishes in the Gila River Basin of ArizonaNew Mexico, USA, and Sonora, Mexico. With respect to this challenging subject, Game et al. (2013) have identi- 
fied six common mistakes in conservation priority setting, i.e., not acknowledging conservation plans are prioritisations, trying to solve an ill-defined problem, not prioritising actions, arbitrariness, hidden value judgments, and not acknowledging risk of failure. These errors may unintentionally arise from authors' attempts to apply quantitative approaches to the problem. In order to avoid perpetuating them, Game et al. (2013) strongly encourage conservation planners to learn more about the well developed if unfamiliar field of decision science.

\section{Prevention is better than cure}

The principle of prevention is better than cure is appropriate to most biological conservation issues and particularly to those relating to aquatic inland habitats. Once impacted, often over the course of years and decades, such sump systems tend to resist immediate and simple restoration as has been shown particularly well for eutrophicated lake systems all around the world (Moss, 2012). A similar resistance is shown by most other conservation problems.

In particular, prevention is by far the best conservation management option in the context of the global problem of invasions by exotic species in fresh waters. With some notable exceptions such as the removal of non-native fish species from relatively small water bodies (Britton et al., 2008), preventative action in the form of biosecurity measures is the only way in which this issue can be managed at a significant scale. Such species introductions can occur entirely accidentally, as is the case with a range of relatively small species such as the diatom Didymosphenia geminate (Lyngbye) (Reid et al., 2012) inadvertently transported by water users and other vectors. However, biota may also be moved deliberately for various reasons, amongst which the most common and probably most consequential is the introduction of fish species for fisheries practices or development for which informed risk assessments are now commonly undertaken (Rowe and Wilding, 2012). Unfortunately, fish species introductions also have an extensive history of being carried out by unauthorised and poorly-informed parties. In such circumstances, appropriate preventative legislative actions, such as local bans on the use of freshwater fish species as live baits, are best supported by educational initiatives (e.g. Winfield and Durie, 2004). It is clear that the future successful management of the invasive species problem in aquatic inland habitats is inextricably linked to educating and/or nudging appropriate human behaviours and the societal perception of associated environmental risks (Cliff and Campbell, 2012).

\section{Emergency rescues through captive breeding or translocation}

Where prevention has failed, the intuitive next step for a substantial number of environmental managers is some form of emergency rescue for particularly important animal or plant populations. Returning to the theme of freshwater fishes, the history of fisheries management is replete with many examples of such activities undertaken at various scales and with various degrees of sophistication. The two main categories of such interventions are the captive breeding of selected individuals to supplement the original population in its threatened original habitat and the translocation of a population (or more commonly a component of it or its offspring) from a threatened habitat to a safer area. The associated literature on freshwater fishes is voluminous and harbours numerous controversies (OgutuOhwayo and Hecky, 1991; Hickley and Chare, 2004; Clarkson et al. 2005; Nishizawa et al., 2006; Gozlan, 2008; itule et al., 2009), arising in part from the contrasting philosophies of different types of manager and in part from the considerable technical difficulties inherent in determining the actual success of such activities. Similar, if less explosive, disagreements have arisen in corresponding programmes addressing other freshwater taxa. For example, Gum et al. (2011) provide a critical reflection on the success of rearing and culturing threatened freshwater pearl mussels (Margaritifera margaritifera L.) in captivity and conclude that such action can be a useful last-minute rescue tool in order to retain populations which would not persist long enough to benefit from habitat restoration practices. Similarly, the closely related action of translocation (also known as managed relocation) may have both positive and negative outcomes and so must be carefully appraised before implementation (Olden et al., 2010). Although many conservationists object to such 'emergency rescues', they do undoubtedly have their place in specific circumstances. For example, returning to the voluminous freshwater fish literature, the threatened vendace [Coregonus albula (L.)] population of Bassenthwaite lake, UK, was successfully translocated to a new lake only years before its local extinction (Winfield et al., 2012).

\section{Long-haul missions of habitat rehabilitation or restoration}

The above translocation example involving the vendace population of Bassenthwaite lake also addresses the issue of habitat management to achieve rehabilitation or even, ultimately, restoration to the original pre-disturbance state. However, as discussed by Winfield et al. (2012) such environmental measures in aquatic inland habitats usually take many years if not decades, with considerable shorter-term variability due to local variations in weather and other factors. These activities are very much long-haul missions involving challenging actions such as the reduction of nutrient loadings entering a water body from its catchment. Similarly, addressing the problems of disrupted hydrological connectivity in flowing waters and their associated still waters is a major and 
long-term undertaking (Pringle, 2001). It is inappropriate and indeed impossible to review and discuss such environmental management measures here, but it is emphasised in a continuation of a theme introduced above that conservation researchers, managers and practitioners must be realistic in their objectives and timescales for such programmes. Moreover, they must initiate positive steps to communicate such information to the diverse range of stakeholders typically interested in the world's aquatic inland habitats.

\section{CONCLUSIONS}

Around the world, the biological conservation of aquatic inland habitats is undoubtedly confronted by many and varied substantial problems. Moreover, in many countries these challenges must now be addressed by researchers and managers in a general climate of reduced direct resources.

The history of scientific understanding of fresh waters is relatively long and relatively detailed when compared with those achieved for other major habitat types, with significant components of this understanding having originally been driven by critical applied concerns such as the provision of clean drinking water and the management of fisheries. Nevertheless, further cost-effective and major advances in practical conservation can be achieved if the volume and rate of knowledge transfer from researchers to managers is enhanced. The case for such action cannot be over-emphasised and the onus surely and rightly lies on the scientific community to make it happen. Such promotion of evidence-based best practice should include not only exciting new areas of science and their applications, but for the sake of management efficiencies and heeding the warning of Sutherland (2003) it should also consider established conventional dogma. A telling aquatic example of this pressing need to assess established practices is provided by Palmer et al. (2009) in a review of the intuitively obvious and long-practiced activity of increasing habitat heterogeneity in river restoration programmes. Remarkably, it was found that this dominant paradigm is not actually supported by the scientific literature. While deploying resources to increase general habitat heterogeneity is unlikely to do any ecological harm, the telling lesson from this critical review is that such limited resources would be more effectively deployed by directing them at identifying and addressing specific problems most likely to limit rehabilitation.

It is also apparent that citizen science has much to offer the conservation of fresh waters, including furthering both their scientific understanding and actually delivering conservation management on the ground and in the water. Such 'popular' activities should not be viewed as a replacement for the traditional professional scientific approach, but welcomed as a way of offering scientists, and others, additional resources and new ways to tackle the considerable environmental challenges facing society. Now more than ever, people are interested in conservation and sustainability. Post-industrial society has never been so aware of the natural environment, which is rightly increasingly visible in some aspects of our popular culture (Fig. 4). There are substantial challenges ahead, but these are better days for the public awareness of aquatic inland habitats and their biological conservation.

\section{ACKNOWLEDGMENTS}

The emphasis and views expressed here are my own, but they have formed as a result of my involvement in a variety of conservation research and management activities involving aquatic inland habitats over many years. My time for considered reflection on these issues has been funded primarily by the Natural Environment Research Council, although significant funding for specific projects has been provided by the Countryside Council for Wales (now Natural Resources Wales), Environment Agency, Natural England, Scottish Natural Heritage and United Utilities. I would also like to thank near and distant colleagues, too numerous to name individually, for their contributions to discussions and exchanges of information which have shaped and enthused my involvement with these fascinating and invaluable habitats. Finally, I also greatly appreciate constructive comments received from two anonymous reviewers which have significantly improved this review and so I thank them for their time and effort.

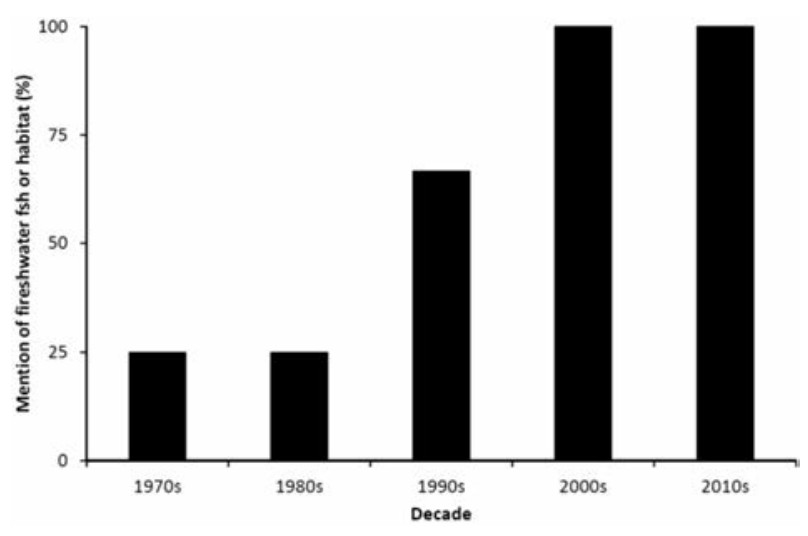

Fig. 4. Increasing incidence from the early 1970 s to the mid 2010s of aquatic inland habitats (expressed as the percentage of each decade's albums containing at least one explicit reference to freshwater fish or freshwater habitat) in the lyrics of the singer/songwriter Bruce Springsteen. Consecutive album sample sizes by decade are 4, 4, 3, 5 and $2(\mathrm{~N}=18)$. Data sourced from www.brucespringsteen.net and figure updated from Winfield (2010). 


\section{REFERENCES}

Alahuhta J, Heino J, Luoto M, 2011. Climate change and the future distributions of aquatic macrophytes across boreal catchment. J. Biogeogr. 38:383-393.

Argillier C, Caussé S, Gevrey M, Pédron S, De Bortoli J, Brucet S, Emmrich M, Jeppesen E, Lauridsen T, Mehner T, Olin M, Rask M, Volta P, Winfield IJ, Kelly F, Krause T, Palm A, Holmgren K, 2012. Development of a fish-based index to assess the eutrophication status of European lakes. Hydrobiologia 704:193-211.

Baldwin RF, Calhoun AJK, DeMaynadier PG, 2006. Conservation planning for amphibian species with complex habitat requirements: a case study using movements and habitat selection of the wood frog Rana sylvatica. J. Herpet. 40:443-454.

Bain MB, Hughes TC, Arend KK, 1999. Trends in methods for assessing freshwater habitats. Fisheries 24:16-21.

Beger M, Grantham HS, Pressey RL, Wilson KA, Peterson EL, Doftman D, Mumby PJ, Lourival R, Brumbaugh DR, Possingham HP, 2010. Conservation planning for connectivity across marine, freshwater, and terrestrial realms. Biol. Conserv. 143:565-575.

Bernazzani P, Bradley BA, Opperman JJ, 2012. Integrating climate change in habitat conservations plans under the U.S. Endangered Species Act. Environ. Manage. 49:1103-1114.

Biggs J, Williams P, Whitfield M, Nicolet P, Weatherby A, 2005. 15 years of pond assessment in Britain: results and lessons learned from the work of Pond Conservation. Aquat. Conserv. 15:693-714.

Bonar SA, Hubert WA, Willis DW, 2009. Standard methods for sampling North American freshwater fishes. American Fisheries Society, Bethesda: 335 pp.

Britton JR, Brazier M, Davies GD, Chare SI, 2008. Case studies on eradicating the Asiatic cyprinid Pseudorasbora parva from fishing lakes in England to prevent their riverine dispersal. Aquat. Conserv 18:867-876.

Brown LE, Mitchell G, Holden J, Folkard A, Wright N, BeharryBorg N, Berry G, Brierley B, Chapman P, Clarke SJ, Cotton L, Dobson M, Dollar E, Fletcher M, Foster J, Hanlon A, Hildon S, Hiley P, Hillis P, Hoseason J, Johnston K, Kay P, McDonald A, Parrott A, Powell A, Slack RJ, Sleigh A, Spray C, Tapley K, Underhill R, Woulds C, 2010. Priority water research questions as determined by UK practitioners and policy makers. Sci. Tot. Env. 409:256-266.

Bruhn LC, Soranno PA, 2005. Long term (1974-2001) volunteer monitoring of water clarity trends in Michigan lakes and their relation to ecoregion and land use/cover. Lake Res. Manage. 21:10-23.

Bunn AG, Urban DL, Keitt TH, 2000. Landscape connectivity: a conservation application of graph theory. J. Environ. Manage. 59:265-278.

ciBioBase, 2012. Crowd source lake mapping. Accessed on 27 June 2012. Available from: http://cibiobase.blogspot.co.uk/ 2012/06/wisdom-of-crowd.html

Clarkson RW, Marsh PC, Dowling TE, 2012. Population prioritization for conservation of imperiled warmwater fishes in an arid-region drainage. Aquat. Conserv 22:498-510.

Clarkson RW, Marsh PC, Stefferud SE, Stefferud JA, 2005. Conflicts between native fish and non-native sport fish management in the southwestern United States. Fish. 30:20-27.

Cliff N, Campbell ML, 2012. Perception as a tool to inform aquatic biosecuirity risk assessments. Aquatic Invasions 7:387-404.

Cooke SJ, Murchie KJ, 2013. Status of aboriginal, commercial and recreational inland fisheries in North America: past, present and future. Fish. Manage. Ecol. DOI: 10.1111/ fme. 12005

Cooke SJ, Hunch SG, Donaldson MR, Clark TD, Eliason EJ, Crossin GT, Raby GD, Jeffries KM, Lapointe M, Miller, K, Patterson DA, Farrell AP, 2013a. Conservation physiology in practice: how physiological knowledge has improved our ability to sustainably manage Pacific salmon during up-river migration. Philos. T. R. Soc. B 367:1757-1769.

Cooke SJ, Sack L, Franklin CE, Farrell AP, Beardall J, Wikelski M, Chown SL, 2013b. What is conservation physiology? Perspectives on an increasingly integrated and essential science. Conserv. Physiol. DOI: 10.1093/conphys/cot001.

D'Sousa RD, Nagendra H, 2011. Changes in public commons as a consequence of urbanization: the Agara lake in Bangalore, India. Environ. Manage. 47:840-850.

Dudgeon D, Arthington AH, Gessner MO, Kawabata Z-I, Knowler DJ, Lévêque C, Naiman RJ, Prieur-Richard A-H, Soto D, Stiassny MLJ, Sullivan CA, 2006. Freshwater biodiversity: importance, threats, status and conservation challenges. Biol. Rev. 81:163-182.

Dugan PJ, Barlow C, Agostinho AA, Baran E, Cada GF, Chen D, Cowx IG, Ferguson JW, Jutagate T, Mallen-Cooper M, Marmulla G, Nestler J, Petere M, Welcomme RL, Winemiller KO, 2010. Fish migration, dams, and loss of ecosystem services in the Mekong Basin. Ambio 39:344-348.

Duncan JR, Lockwood JL, 2001. Extinction in a field of bullets: a search for causes in the decline of the world's freshwater fishes. Biol. Conserv. 102:97-105.

Dunham JB, Adams SB, Schroeter RE, Novinger DC, 2002. Alien invasions in aquatic ecosystems: toward an understanding of brook trout invasions and potential impacts on inland cutthroat trout in western North America. Rev. Fish Biol. Fish. 12:373-391.

Emmrich M, Winfield IJ, Guillard J, Rustadbakken A, Vergés C, Volta P, Jeppesen E, Lauridsen TL, Brucet S, Holmgren K, Argillier A, Mehner T, 2012. Strong correspondence between gillnet catch per unit effort and hydroacoustically derived fish biomass in stratified lakes. Freshwater Biol. 57:2436-2448.

European Communities, 1992. Directive 92/43/EEC, on the conservation of natural habitats and of wild fauna and flora. In: Official Journal, L 206, p. 7-50.

European Communities, 2000. Directive 2000/60/EC, establishing a framework for community action in the field of water policy. In: Official Journal, L 327, p. 1-71.

European Standard, 2005. Water quality - sampling of fish with multimesh gillnets. European Standard EN 14757.

European Standard, 2006. Water quality - guidance on the scope and selection of fish sampling methods. European Standard EN14962.

Fletcher M, 2013 Algal bloom pilot project. FBA News No. 57 Summer 2012, p. 22-23.

Game ET, Kareiva P, Possingham HP, 2013. Six common mistakes in conservation priority setting. Conserv. Biol. DOI: 10.1111/cobi.12051

Gopal B, 2005. Does inland aquatic biodiversity have a future 
in Asian developing countries? Hydrobiologia 542:69-75.

Gozlan RE, 2008. Introduction of non-native freshwater fish: is it all bad? Fish Fish. 9:106-115.

Gum B, Lange M, Geist J, 2011. A critical reflection on the success of rearing and culturing juvenile freshwater mussels with a focus on the endangered freshwater pearl mussel (Margaritifera margaritifera L.). Aquat. Conserv.. 21:743-751.

Hateley J, Clabburn P, Drastik V, Godlewska M, Guillard J, Kubecka J, Morrissey E, Thackeray SJ, Winfield IJ, 2013. Standardisation of hydroacoustic techniques for fish in fresh waters, p. 1595-1600. In: J.S. Papadakis and L. Bjorno (eds.), Proc. $1^{\text {st }}$ Underwater Acoustics Int. Conf., Corfu, Greece.

Herbert ME, McIntyre PB, Doran PJ, Allan JD, Abell R, 2010. Terrestrial reserve networks do not adequately represent aquatic ecosystems. Conserv. Biol. 24:1002-1011.

Hermoso V, Clavero M, Blanco-Garrido F, Prenda J, 2011. Invasive species and habitat degradation in Iberian streams: an analysis of their role in freshwater fish diversity loss. Ecol. Appl. 21:175-188.

Hickley P, Chare S, 2004. Fisheries for non-native species in England and Wales: angling or the environment? Fish. Manage. Ecol. 11:203-212.

Holland RA, Darwall WRT, Smith KG, 2012. Conservation priorities for freshwater biodiversity: the Key Biodiversity Area approach refined and tested for continental Africa. Biol. Conserv. 148:167-179.

Holling CS, 1978. Adaptive Environmental Assessment and Management. John Wiley \& Sons, Chichester: 377 pp.

Hussner A, Van de Weyer K, Gross EM, Hilt S, 2010. Comments on increasing number and abundance of non-indigenous aquatic macrophyte species in Germany. Weed Res. 50:519-526.

Jeppesen E, Mehner T, Winfield IJ, Kangur K, Sarvala J, Gerdeaux D, Rask M, Malmquist HJ, Holmgren K, Volta P, Romo S, Eckmann R, Sandström A, Blanco S, Kangur A, Ragnarsson Stabo H, Tarvainen M, Ventelä A-M, Søndergaard M, Lauridsen TL, Meerhoff M, 2012. Impacts of climate warming on the long-term dynamics of key fish species in 24 European lakes. Hydrobiologia 694:1-39.

Jerde CL, Mahon AR, Chadderton WL, Lodge DM, 2011. "Sight-unseen" detection of rare aquatic species using environmental DNA. Conserv. Lett. 4:150-157.

Kats LB, Ferrer RP, 2003. Alien predators and amphibian declines: review of two decades of science and the transition to conservation. Divers. Distrib. 9:99-110.

Koperski P, 2010. Urban environments as habitats for rare aquatic species: the case of leeches (Euhirudinea, Clitellata) in Warsaw freshwaters. Limnologica 40:233-240.

Kubečka J, Amarasingh US, Bonar SA, Hateley J, Hickley P, Hohausová E, Matěna J, Peterka J, Suuronen P, Tereschenko V, Welcomme R, Winfield IJ. 2009. The true picture of a lake or reservoir fish stock: A review of needs and progress. Fish. Res. 96:1-5.

Langford TEL, Shaw PJ, Howard SR, Ferguson AJD, Ottewell D, Eley R, 2010. Ecological recovery in a river polluted to its sources: the River Tame in the English Midlands, p. 255275. In: L.C. Batty and K.B. Hallberg (eds.), Ecology of industrial pollution. Cambridge University Press.

Lee KN, 1993. Compass and gyroscope: integrating science and politics in the environment. Island Press, Washington: 243 pp.
Leidy RA, Cervantes-Yoshida K, Carlson SM, 2011. Persistence of native fishes in small streams of the urbanized San Francisco Estuary, California: acknowledging the role of urban streams in native fish conservation. Aquat. Conserv. 21:472-483.

Liu X, Guo Z, Ke Z, Wang S, Li Y, 2011. Increasing potential risk of a global aquatic invader in Europe in contrast to other continents under future climate change. PLoS One 6:e18429.

LWEC, 2012. Most wanted II: postgraduate and professional skills needs in the environment sector. LWEC Report 2012. Natural Environment Research Council, Swindon, UK: 20 pp.

Maitland PS, 1974. The conservation of freshwater fishes in the British Isles. Biol. Conserv. 6:7-14.

May L, Spears BM, 2012a. A history of scientific research at Loch Leven, Kinross, Scotland. Hydrobiologia 681:3-9.

May L, Spears BM, 2012b. Managing ecosystem services at Loch Leven, Scotland, UK: actions, impacts and unintended consequences. Hydrobiologia 681:117-130.

McCallum ML, Bury GW, 2013. Google search patterns suggest declining interest in the environment. Biodivers. Conserv. DOI: $10.1007 / \mathrm{s} 10531-013-0476-6$

McGregor Reid G, 2013. Introduction to freshwater fishes and their conservation. Int. Zoo Yb. 47:1-5.

Md Rawi CS, Al-Shami SA, Madrus MR, Ahmad AH, 2013. Local effects of forest fragmentation on diversity of aquatic insects in tropical forest streams: implications for biological conservation. Aquat. Ecol. 47:75-85.

Moore AA, Palmer MA, 2005. Invertebrate biodiversity in agricultural and urban headwater streams: implications for conservation and management. Ecol. Appl. 15:1169-1177.

Moss B, 2012. Liberation ecology: the reconciliation of natural and human cultures. International Ecology Institute, Oldendorf: 433 pp.

Moyle PB, Leidy RA, 1992. Loss of biodiversity in aquatic ecosystems: evidence from fish faunas, p. 128-169. In: P.L. Fiedler and S.A. Jain (eds.), Conservation biology: the theory and practice of nature conservation, preservation, and management. Chapman and Hall, New York.

Newman G, Wiggins A, Crall A, Graham E, Newman S, Crowston K, 2012. The future of citizen science: emerging technologies and shifting paradigms. Front. Ecol. Environ 10:298-304.

Nishizawa E, Kurokawa T, Yabe M, 2006. Policies and resident's willingness to pay for restoring the ecosystem damaged by alien fish in lake Biwa, Japan. Env. Sci. Policy 9: 448-456.

Ogutu-Ohwayo R, Hecky R, 1991. Fish introductions in Africa and some of their implications. Can. J. Fish. Aquat. Sci. 48(Suppl.1):8-12.

Olden JD, Kennard MJ, Lawler JJ, Poff NL, 2010. Challenges and opportunities in implementing managed relocation for conservation of freshwater species. Conserv. Biol. 25:40-47.

O'Hare MT, Gunn IDM, Chapman DS, Dudley BJ, Purse BV, 2012. Impacts of space, local environment and habitat connectivity on macrophyte communities in conservation lakes. Divers. Distrib. 18:603-614.

Palmer MA, Menninger HL, Bernhardt E, 2009. River restoration, habitat heterogeneity and biodiversity: a failure of theory or practice? Freshwater Biol. 55(Suppl.1):1-18. 
Pecorelli J, 2012. The Zoological Society of London's Citizen Science, European Eel Monitoring Programme. FBA News No. 58 Autumn/Winter 2012/2013:4-5.

Pringle CM, 2001. Hydrologic connectivity and the management of biological reserves: a global perspective. Ecol. Appl. 11:981-998.

Recuero E, Cruzado-Cortes J, Parra-Olea G, Zamudio KR, 2010. Urban aquatic habitats and conservation of highly endangered species: the case of Ambystoma mexicanum (Caudata, Ambystomatidae). Ann. Zool. Fennici 47:223-238.

Reid BL, Hernández KL, Frangópulos M, Bauer G, Lorca M, Kilro C, Spaulding S, 2012. The invasion of the freshwater diatom Didymosphenia geminate in Patagonia: prospects, strategies, and implications for biosecurity of invasive microorganisms in continental waters. Conserv. Lett. 5:432-440.

Rowe DK, Wilding T, 2012. Risk assessment model for the introduction of non-native freshwater fish into New Zealand. J. Appl. Ichthyol. 28:582-589.

Silvertown J, 2009. A new dawn for citizen science. Trends. Ecol. Evol. 24:467-471.

Strecker AL, Olden JD, Whittier JB, Paukert CP, 2011. Defining conservation priorities for freshwater fishes according to taxonomic, functional, and phylogenetic diversity. Ecol. Appl. 21:3002-3013.

Sutherland W, 2003. Evidence-based conservation. Conserv. Prac. 4:39-42.

Sutherland W, Adams WM, Aronson RB, Aveling R, Blackburn TM, Broad S, Ceballos G, Côté IM, Cowling RM, Da Fonseca GAB, Dinerstein E, Ferraro PJ, Fleishman E, Gascon C, Hunter Jr M, Hutton J, Kareiva P, Kuria A, MacDonald DW, MacKinnon K, Madgwick FJ, Mascia MB, McNeely J, Milner-Gulland EJ, Moon S, Morley CG, Nelson S, Osborn D, Pai M, Parsons ECM, Peck LS, Possingham H, Prior SV, Pullin AS, Rands MRW, Ranganathan J, Redford KH,
Rodriguez JP, Seymour F, Sobel J, Sodhi NS, Stott A, VanceBorland K, Watkinson AR, 2009. One hundred questions of importance to the conservation of global biological diversity. Conserv. Biol. 23:557-567.

Vermonden K, Leuven RSEW, van der Velde G, van Katwijk MM, Roelofs JGM, Hendriks AJ, 2009. Urban drainage systems: An undervalued habitat for aquatic macroinvertebrates. Biol. Conserv. 142:1105-1115.

Vitule JRS, Freire CA, Simberloff D, 2009. Introduction of non-native freshwater fish can certainly be bad. Fish Fish. 10:98-108.

Watzin MC, Smyth RL, Cassell EA, Hession WC,Manning R, Wang D, 2005. Ecological indicators and an environmental scorecard for the lake Champlain Basin Program. Report to the lake Champlain Basin Program, Grand Isle, Vermont. LCBP Technical Report Series No. 46.

Winfield IJ, 2010. Meeting across the river: from science to impact. Aquat. Conserv. 20:607-610.

Winfield IJ, Durie NC, 2004. Fish introductions and their management in the English Lake District. Fish. Manage. Ecol. 11:1-7.

Winfield IJ, Fletcher JM, James JB, 2011. Invasive fish species in the largest lakes of Scotland, Northern Ireland, Wales and England: the collective U.K. experience. Hydrobiologia 660:93-103.

Winfield IJ, Fletcher JM, James JB, Bean CW, 2009. Assessment of fish populations in still waters using hydroacoustics and survey gill netting: experiences with Arctic charr (Salvelinus alpinus) in the U.K. Fish. Res. 96:30-38.

Winfield IJ, Adams CE, Bean CW, Durie NC, Fletcher JM, Gowans AR, Harrod C, James JB, Lyle AA, Maitland PS, Thompson C, Verspoor E, 2012. Conservation of the vendace (Coregonus albula), the U.K.'s rarest freshwater fish. Adv. Limnol. 63:547-559. 